\title{
An Improved Antagonist Radiotracer for the к-Opioid Receptor: Synthesis and Characterization of ${ }^{11}$ C-LY2459989
}

\author{
Ming-Qiang Zheng ${ }^{1}$, Su Jin Kim ${ }^{1}$, Daniel Holden ${ }^{1}$, Shu-fei Lin ${ }^{1}$, Anne Need ${ }^{2}$, Karen Rash ${ }^{2}$, Vanessa Barth ${ }^{2}$, \\ Charles Mitch ${ }^{2}$, Antonio Navarro ${ }^{2}$, Michael Kapinos ${ }^{1}$, Kathleen Maloney ${ }^{1}$, Jim Ropchan ${ }^{1}$, Richard E. Carson ${ }^{1}$, \\ and Yiyun Huang ${ }^{1}$ \\ ${ }^{I}$ PET Center, Department of Diagnostic Radiology, Yale University, New Haven, Connecticut; and ${ }^{2}$ Eli Lilly \& Company, \\ Indianapolis, Indiana
}

The K-opioid receptors (KORs) are implicated in several neuropsychiatric diseases and addictive disorders. PET with radioligands provides a means to image the KOR in vivo and investigate its function in health and disease. The purpose of this study was to develop the selective KOR antagonist ${ }^{11}$ C-LY2459989 as a PET radioligand and characterize its imaging performance in nonhuman primates. Methods: LY2459989 was synthesized and assayed for in vitro binding to opioid receptors. Ex vivo studies in rodents were conducted to assess its potential as a tracer candidate. ${ }^{11} \mathrm{C}$ LY2459989 was synthesized by reaction of its iodophenyl precursor with ${ }^{11} \mathrm{C}$-cyanide, followed by partial hydrolysis of the resulting ${ }^{11} \mathrm{C}$-cyanophenyl intermediate. Imaging experiments with ${ }^{11} \mathrm{C}$ LY2459989 were performed in rhesus monkeys with arterial input function measurement. Imaging data were analyzed with kinetic models to derive in vivo binding parameters. Results: LY2459989 is a full antagonist with high binding affinity and selectivity for KOR $(0.18,7.68$, and $91.3 \mathrm{nM}$, respectively, for $\mathrm{K}, \mu$, and $\delta$ receptors). Ex vivo studies in rats indicated LY2459989 as an appropriate tracer candidate with high specific binding signals and confirmed its KOR binding selectivity in vivo. ${ }^{11} \mathrm{C}-$ LY2459989 was synthesized in high radiochemical purity and good specific activity. In rhesus monkeys, ${ }^{11} \mathrm{C}$-LY2459989 displayed a fast rate of peripheral metabolism. Similarly, ${ }^{11} \mathrm{C}$-LY2459989 displayed fast uptake kinetics in the brain and an uptake pattern consistent with the distribution of $\mathrm{KOR}$ in primates. Pretreatment with naloxone $(1 \mathrm{mg} / \mathrm{kg}$, intravenously) resulted in a uniform distribution of radioactivity in the brain. Further, specific binding of ${ }^{11} \mathrm{C}-\mathrm{LY} 2459989$ was dosedependently reduced by the selective KOR antagonist LY2456302 and the unlabeled LY2459989. Regional binding potential values derived from the multilinear analysis-1 (MA1) method, as a measure of in vivo specific binding signal, were 2.18, 1.39, 1.08, 1.04, $1.03,0.59,0.51$, and 0.50 , respectively, for the globus pallidus, cingulate cortex, insula, caudate, putamen, frontal cortex, temporal cortex, and thalamus. Conclusion: The novel PET radioligand ${ }^{11}$ C-LY2459989 displayed favorable pharmacokinetic properties, a specific and KOR-selective binding profile, and high specific binding signals in vivo, thus making it a promising PET imaging agent for KOR.

\footnotetext{
Received Feb. 8, 2014; revision accepted Mar. 25, 2014.

For correspondence or reprints contact: Yiyun (Henry) Huang, PET Center, Department of Diagnostic Radiology, Yale University School of Medicine,

P.O. Box 208048, 801 Howard Ave., New Haven, CT 06520-8048.

E-mail: henry.huang@yale.edu

Published online May 22, 2014.

COPYRIGHT (C) 2014 by the Society of Nuclear Medicine and Molecular Imaging, Inc.
}

Key Words: kappa opioid receptor; antagonist; PET; radioligand; synthesis and evaluation

J Nucl Med 2014; 55:1185-1191

DOI: 10.2967/jnumed.114.138701

$\mathbf{T}$ he opioid receptors (ORs) are G-protein-coupled receptors with at least 3 subtypes: $\mu, \kappa$, and $\delta(1)$. The ORs share extensive homology but differ in their pharmacology and physiologic effects (2). The presence of $\kappa$-opioid receptors (KORs) is widespread in the human brain and is found in greater density than the $\mu$-opioid receptor (MOR) in most brain regions (3-5). KORs are present in the deep layers of cortical regions and in the striatum, hippocampus, amygdala, and thalamus $(3,5,6)$. A similar distribution of KORs is seen in the nonhuman primate brain $(7,8)$.

KORs are implicated in the pathophysiology of a variety of neuropsychiatric diseases and addictive disorders (9). For example, multiple lines of evidence point to the involvement of KORs in depression and related mood disorders (10-16). In turn, these findings raise the possibility that KOR antagonists might be efficacious antidepressants. As such, KORs are a target for development of newer antidepressants. In addition, the role of the opioid system in alcohol addiction and treatment is well established, as the nonselective opioid antagonist naltrexone is effective in the prevention of relapse in some alcoholics (17). There is also a large body of literature indicating that the opioid system, especially the KOR, is critically involved in the biology of addiction to psychostimulants, and thus pharmacologic intervention at the KOR/dynorphin system may be an effective avenue for treatment of drug and alcohol abuse (18).

Because KORs are involved in several psychiatric diseases and addictive disorders, the successful deployment of a PET imaging agent for use in humans will allow the noninvasive investigation of the KOR in vivo and lead to new understandings of its function and dysfunction/dysregulation in these disorders. It will also make it possible to correlate and translate preclinical findings in animal models to humans and help in the development of novel therapeutic agents by correlating dose, pharmacokinetic parameters, and receptor occupancy.

Several radiotracers are currently available for imaging the ORs in humans. They include ${ }^{11} \mathrm{C}$-carfentanil, ${ }^{11} \mathrm{C}-/{ }^{18} \mathrm{~F}$-diprenorphine, ${ }^{11} \mathrm{C}$-buprenorphine, ${ }^{11} \mathrm{C}$-cyclofoxy, and ${ }^{11} \mathrm{C}$-methylnaltrindole $(19,20)$. None of these ligands can be used to selectively image KOR in vivo. Over the years, many groups have attempted to 
develop KOR-selective PET radioligands, such as the agonist ligands ${ }^{11} \mathrm{C}-\mathrm{GR} 89696$ and ${ }^{11} \mathrm{C}-\mathrm{GR} 103545$ and the antagonist ligand ${ }^{11} \mathrm{C}-$ MeJDTic (Fig. 1) (21-24). However, only ${ }^{11} \mathrm{C}-\mathrm{GR} 103545$ has been evaluated extensively in nonhuman primates and recently in humans in our laboratory (25-28). We previously reported the synthesis of ${ }^{11} \mathrm{C}$-LY2795050 as the first-ever selective antagonist radioligand able to image the KOR in nonhuman primates and humans (29). In this paper, we report the discovery and characterization of ${ }^{11} \mathrm{C}-\mathrm{LY} 2459989\left({ }^{11} \mathrm{C}-5\right.$, Fig. 1) as a KOR-selective radioligand with improved imaging characteristics over ${ }^{11} \mathrm{C}-\mathrm{LY} 2795050$.

\section{MATERIALS AND METHODS}

\section{Chemistry}

Synthesis of LY2459989 and the radiolabeling precursor for ${ }^{11} \mathrm{C}$ LY2459989 is described in the supplemental materials (available at http://jnm.snmjournals.org).

\section{In Vitro Binding Assays}

In vitro binding experiments and GTP- $\gamma$-S antagonist functional assays were performed according to the published procedures (30).

\section{Ex Vivo Experiments in Rodents: Tracer Distribution and Receptor Occupancy Studies}

Male Sprague-Dawley rats (225-300 g; Harlan Laboratories) were group-housed with ad libitum food and water and maintained on a 12h light-dark cycle. All experiments were conducted under protocols approved by the Institutional Animal Care and Use Committee of Eli Lilly \& Co.

LY2459989 was dissolved in 25\% 3-hydroxypropyl- $\beta$-cyclodextrin at a concentration of $6 \mu \mathrm{g} / \mathrm{mL}$ and administered intravenously via the lateral tail at a dose of $3 \mu \mathrm{g} / \mathrm{kg}$ to groups of rats (4 rats in each group) in a volume of $0.5 \mathrm{~mL} / \mathrm{kg}$. Animals were sacrificed at $5,20,40$, or 60 min after LY2459989 injection. The striatum and cerebellum were dissected, weighed, and positioned in conical centrifuge tubes placed on ice. Four volumes (w/v) of acetonitrile containing $0.1 \%$ formic acid were added to each tube. These samples were then homogenized using an ultrasonic probe (7-8 watts power using a sonic probe dismembrator; Fisher Scientific) and centrifuged at 14,000 rpm for $16 \mathrm{~min}$. The supernatant was separated and diluted 1:4 with sterile water in high-performance liquid chromatography (HPLC) injection vials for LC/MS/MS analysis using a model 1200 HPLC (Agilent Technologies) system and an API 4000 mass spectrometer (Applied Biosystems). The chromatographic separation used a Zorbax Eclipse XDB-C18 column $(2.1 \times 50 \mathrm{~mm}, 3.5$ $\mu \mathrm{m}$; Agilent) and a mobile phase gradient of acetonitrile (A) and water
(B), each containing $0.1 \%$ formic acid over $5 \min (5 \%$ A for $1 \mathrm{~min}$, then increasing to $95 \%$ A from 1 to $2 \mathrm{~min}$ and holding from 2 to $3 \mathrm{~min}$, decreasing to $5 \% \mathrm{~A}$ at $3.1 \mathrm{~min}$ and holding until $5 \mathrm{~min}$ ), at a flow rate of $0.25 \mathrm{~mL} / \mathrm{min}$. Detection of LY2459989 was accomplished by monitoring the precursor to product ion transition with a mass-to-charge ratio $(\mathrm{m} / \mathrm{z})$ of 392.301 to 244 . Standards were prepared by adding known quantities of LY2459989 to brain tissue samples from nontreated rats and processed as described above. Concentrations of LY2459989 in the striatum were presumed to represent total binding, whereas levels in the cerebellum represented nonspecific binding because this is a region with little or no expression of ORs (31). The concentration ratio between striatum and cerebellum is presented as a measure of specific binding.

Occupancies of LY2459989 at KOR, MOR, and DOR were determined using an in vivo rat model of central receptor occupancy and the procedures described previously, with GR103545, naltrexone, and naltriben as in vivo tracers for KOR, MOR, and DOR, respectively (32). They were injected intravenously $1 \mathrm{~h}$ after oral administration of vehicle or LY2459989 (0.01, 0.03. 0.1, 0.3, 1, 3, 10, or 30 mg/kg). Animals were sacrificed by cervical dislocation $30 \mathrm{~min}$ after tracer administration. Tracer analysis was performed using a model $6460 \mathrm{MS} / \mathrm{MS}$ system equipped with a 1260 HPLC system (Agilent Technologies). The chromatographic separation was performed with a Zorbax SB-C18 column $(2.1 \times 50 \mathrm{~mm}, 1.8 \mu \mathrm{m}$; Agilent $)$ and gradient of components A $(0.1 \%$ formic acid in acetonitrile) and B (0.1\% formic acid in water) over $3.5 \mathrm{~min}(5 \%$ A for $1 \mathrm{~min}$, then increasing to $90 \%$ A from 1 to $1.75 \mathrm{~min}$ and holding from 1.75 to $2 \mathrm{~min}$, decreasing to $5 \% \mathrm{~A}$ at $2.1 \mathrm{~min}$ and holding until $3.5 \mathrm{~min}$ ) at a flow rate of $0.40 \mathrm{~mL} / \mathrm{min}$. The detection of tracers was accomplished by monitoring ion transitions 414.1/343.0, 342.2/270.2, and 416.0/301.1 mass-to-charge ratio for GR103545, naltrexone, and naltriben, respectively.

\section{Radiochemistry}

Instruments used were as follows: a preparative HPLC system including a Shimadzu LC-20A pump, a Rheodyne 7133i injector with a 2-mL loop, a Knauer K200 ultraviolet detector, a Bioscan $\gamma$-flow detector, and a laptop computer running the EZStart data acquisition software and an analytic HPLC system consisting of a Shimadzu LC20A quarternary pump, a Rheodyne 7133 i injector, a Shimadzu SPDM20A PDA or SPD-20A ultraviolet detector, a flow cell $\gamma$ detector (Bioscan), and a PC with Shimadzu Class VP 7.2 software used for system control. Chiral HPLC analysis was performed with a Chiralpak AS-H column $(4.6 \times 150 \mathrm{~mm})$ eluting with $0.2 \%$ triethylamine in $\mathrm{MeOH}$ at a flow rate of $0.6 \mathrm{~mL} / \mathrm{min}$.

The production of ${ }^{11} \mathrm{C}-\mathrm{CO}_{2}$ was started with the ${ }^{14} \mathrm{~N}(\mathrm{p}, \alpha){ }^{11} \mathrm{C}$ nuclear reaction by bombardment of a mixture of nitrogen and oxygen $(0.5 \%-1 \%)$ with a proton beam. In a highpressure target in a PETtrace cyclotron (GE Healthcare). The cyclotron-produced ${ }^{11} \mathrm{C}$ $\mathrm{CO}_{2}$ was transferred into a ProCab (GE Healthcare) and reacted with hydrogen at $400^{\circ} \mathrm{C}$ under a nickel catalyst to afford ${ }^{11} \mathrm{C}$ methane, which was converted to ${ }^{11} \mathrm{C}$-cyanide by reaction with ammonia over a platinum catalyst at $950^{\circ} \mathrm{C}$. Radiolabeling was performed by trapping ${ }^{11} \mathrm{C}$-cyanide in a solution of precursor 6 (1-3 mg) (Fig. 2), $\mathrm{K}_{2} \mathrm{HCO}_{3}$, $\mathrm{Pd}_{2} \mathrm{dba}_{3}$, and dppf in DMF $(0.3 \mathrm{~mL})$ at room temperature. Reaction at $80^{\circ} \mathrm{C}$ for 5 min produced the intermediate ${ }^{11} \mathrm{C}-7$, which was then treated with $\mathrm{NaOH}(1 \mathrm{~N}, 0.2 \mathrm{~mL})$ and $\mathrm{H}_{2} \mathrm{O}_{2}$ $(0.2 \mathrm{~mL})$ at $80^{\circ} \mathrm{C}$ for $5 \mathrm{~min}$ to afford ${ }^{11} \mathrm{C}$ LY2459989 ( $\left.{ }^{11} \mathrm{C}-5\right)$ (Fig. 2).

Purification was achieved by preparative HPLC using a Genesis C18 column $(10 \times 250 \mathrm{~mm}$,

FIGURE 1. Structures of selected KOR ligands. 
$4 \mu \mathrm{m})$. The column was eluted with $22 \%$ acetonitrile and $78 \% 0.1 \mathrm{M}$ aqueous ammonium formate solution with $0.5 \%$ acetic acid (v/v, $\mathrm{pH}$ 4.2), at a flow rate of $5 \mathrm{~mL} / \mathrm{min}$. The desired product fraction (eluting at 11-13 $\mathrm{min})$ was collected, diluted with water $(50 \mathrm{~mL})$, and passed through a Waters C-18 SepPak cartridge. The cartridge was rinsed with $10 \mathrm{~mL}$ of $0.01 \mathrm{~N} \mathrm{HCl}$ solution. The radioactive product was recovered by eluting the SepPak with $1 \mathrm{~mL}$ of United States Pharmacopeia (USP) absolute ethanol, followed by $3 \mathrm{~mL}$ of USP saline, into a product vial containing $7 \mathrm{~mL}$ of USP saline and $40 \mu \mathrm{L}$ of $4.2 \%$ USP sodium bicarbonate solution. This mixture was then passed through a sterile membrane filter $(0.22 \mu \mathrm{m})$ for terminal sterilization and collected in an empty sterile vial to afford a formulated solution ready for intravenous administration. The chemical purity, radiochemical purity, and specific activity of ${ }^{11} \mathrm{C}$-LY2459989 were determined by HPLC analysis of the final product solution (column: Genesis C18, $4.6 \times 250$ $\mathrm{mm}, 4 \mu \mathrm{m}$; mobile phase: $22 \%$ acetonitrile and $78 \% 0.1 \mathrm{M}$ aqueous ammonium formate with $0.5 \%$ acetic acid [v/v, $\mathrm{pH} 4.2$ ]; flow rate: 2 $\mathrm{mL} / \mathrm{min}$; ultraviolet detector wavelength: $254 \mathrm{~nm}$ ). The identity of the labeled compound was confirmed by coinjection of the product with the unlabeled LY2459989. Radiolabeled product and LY2459989 coeluted on the analytic HPLC (retention time for the product, $\sim 6.3 \mathrm{~min}$ ).

\section{PET Imaging Experiments in Rhesus Monkeys}

PET Procedures. Experiments were performed in rhesus monkeys (Macaca mulatta) according to a protocol approved by the Yale University Institutional Animal Care and Use Committee and procedures as described previously (33).

Three animals were used in this study. In the first set of experiments, a control scan with ${ }^{11} \mathrm{C}$-LY2459989 alone was followed by a blocking scan with intravenous injection of naloxone $(1 \mathrm{mg} / \mathrm{kg})$ at $10 \mathrm{~min}$ before the second injection of ${ }^{11} \mathrm{C}-\mathrm{LY} 2459989$. In the second set of experiments, a ${ }^{11}$ C-LY2459989 baseline scan was followed by a blocking scan either with LY2456302 $(29,30)$ or with unlabeled LY2459989. Twelve PET scans were obtained.

Metabolite Analysis and Arterial Input Function Measurement. Procedures for measurement of the input function have previously been described (29). Arterial samples were collected at preselected time points to measure radioactivity concentrations in plasma and whole blood. Six samples, collected at 2, 5, 15, 30, 60, and 90 min were also processed and analyzed by HPLC to determine the fraction of unmetabolized tracer over time using a column-switching method (34). Procedures for sample preparation, HPLC analysis, and data processing were the same as those previously reported for ${ }^{11} \mathrm{C}-\mathrm{LY} 2795050$ (29). The procedure for plasma-free fraction measurement was also the same.

Image Analysis and Kinetic Modeling. The procedures for PET image reconstruction and definition of regions of interest (ROIs) were the same as described previously (29). For each scan, radiotracer concentrations over time were measured in 15 ROIs.

Total distribution volume $\left(V_{\mathrm{T}}, \mathrm{mL} \cdot \mathrm{cm}^{-3}\right)$ was derived by kinetic analysis of the regional time-activity curves, using the metabolite-corrected arterial plasma concentration as the input function, according to a 1tissue (1T) or 2-tissue (2T)-compartment model as well as the multilinear analysis-1 (MA1) method $(35,36)$. Kinetic parameters $\left(K_{1}\right.$ and $k_{2}$ for the $1 \mathrm{~T}$ model; $K_{1}-k_{4}$ for the $2 \mathrm{~T}$ model) were derived first. In the $1 \mathrm{~T}$ model,

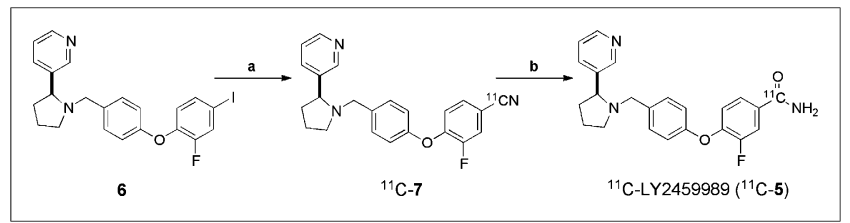

FIGURE 2. Radiosynthesis of ${ }^{11} \mathrm{C}-\mathrm{LY} 2459989$. Reagents and conditions: a. $\mathrm{H}^{11} \mathrm{CN}, \mathrm{KHCO}_{3}, \mathrm{Pd}_{2}(\mathrm{dba})_{3}$, dppf, DMF, $80^{\circ} \mathrm{C}, 5 \mathrm{~min}$; b. $\mathrm{NaOH}$, $\mathrm{H}_{2} \mathrm{O}_{2}, 80^{\circ} \mathrm{C}, 5$ min.
$K_{1}\left(\mathrm{~mL} \cdot \mathrm{min}^{-1} \cdot \mathrm{cm}^{-3}\right)$ and $k_{2}\left(\mathrm{~min}^{-1}\right)$ are the rate constants governing the transfer of the ligand into and out of the brain, respectively. In the $2 \mathrm{~T}$ model, $K_{1}$ and $k_{2}$ are the rate constants governing the transfer of the ligand into and out of the nondisplaceable compartment, whereas $k_{3}$ $\left(\min ^{-1}\right)$ and $k_{4}\left(\min ^{-1}\right)$ describe the respective rates of association to and dissociation from the receptors (36). The values of $V_{\mathrm{T}}$ were calculated from the kinetic parameters as $K_{1} / k_{2}$ in the 1T model and as $\left(K_{1} / k_{2}\right) \times$ $\left(1+k_{3} / k_{4}\right)$ in the $2 \mathrm{~T}$ model (36). The Akaike information criterion (AIC) was used to evaluate the optimal model for regional $V_{\mathrm{T}}$ estimates.

Cerebellar $V_{\mathrm{T}}\left(V_{\mathrm{T} \text { CER }}\right)$ was used as an estimate of the nondisplaceable distribution volume to calculate the regional nondisplaceable binding potential $\left(B P_{\mathrm{ND}}\right)$ as $B P_{\mathrm{ND}}=\left(V_{\mathrm{T} \mathrm{ROI}}-V_{\mathrm{T} \text { CER }}\right) / V_{\mathrm{T} \text { CER }}(36)$.

KOR occupancies by naloxone, LY2456302, or LY2459989 were calculated using $V_{\mathrm{T}}$ values from all 15 ROIs to create occupancy plots according to the method of Cunningham et al. (37).

\section{RESULTS \\ Chemistry}

Both LY2459989 (5, Fig. 1) and its less-active (R)-enantiomer were synthesized in greater than $98 \%$ enantiomeric purity. The radiolabeling precursor (6, Fig. 2) was also prepared in greater than $99 \%$ chemical purity and greater than $99 \%$ enantiomeric purity. Detailed synthetic procedures are described in the supplemental material.

\section{In Vitro Binding Assays and Ex Vivo Evaluation in Rats}

LY2459989 displayed high KOR affinity $\left(K_{\mathrm{i}}=0.18 \mathrm{nM}\right)$ and more than 43-fold selectivity for KOR over other ORs $\left(K_{\mathrm{i}}=7.68\right.$ $\mathrm{nM}$ for MOR and $91.3 \mathrm{nM}$ for DOR) (supplemental materials).

The potential of LY2459989 as a tracer candidate was assessed in rats using an intravenous dose of $3 \mu \mathrm{g} / \mathrm{kg}$ and analysis of tissue concentrations by the LC/MS/MS method (38). A rapid initial brain uptake was seen at 5 min after injection. Ligand concentration was higher in the striatum than cerebellum at all time points (Fig. 3A). The striatum-to-cerebellum concentration ratio, as a measure of specific binding, was 2.9, 4.1, and 4.0, respectively, at 20, 40, and $60 \mathrm{~min}$ after injection.

In vivo binding at $\mathrm{KOR}, \mathrm{MOR}$, and DOR was also assessed with LC/MS/MS after oral administration of ascending doses of LY2459989 using the triple-tracer method (32). Dose-dependent blockade of KOR and MOR binding by LY2459989 was demonstrated (Fig. 3B). The effective doses to produce 50\% receptor occupancy were calculated to be 0.31 and $19.5 \mathrm{mg} / \mathrm{kg}$, respectively, for KOR and MOR. These $E D_{50}$ values translated to a selectivity of approximately 63 folds for KOR over MOR, similar to the selectivity measured in vitro ( $\sim 43$ times; supplemental material and Supplemental Table 1). At the maximum dose administered (30 mg/kg), LY2459989 induced no blockade of DOR binding, consistent with its low affinity for this receptor subtype (Fig. 3B; supplemental material and Supplemental Table 1).

\section{Radiochemistry}

Radiosynthesis of ${ }^{11}$ C-LY2459989 is depicted in Figure 2. Palladium-catalyzed displacement of the iodo group in the precursor by ${ }^{11} \mathrm{C}$-cyanide resulted in the intermediate ${ }^{11} \mathrm{C}-7$, which, without separation and purification, was reacted with $\mathrm{H}_{2} \mathrm{O}_{2}$ under basic condition to afford the amide ${ }^{11} \mathrm{C}-\mathrm{LY} 2459989\left({ }^{11} \mathrm{C}-5\right)$. This 2-step 1-pot radiosynthesis provided ${ }^{11} \mathrm{C}$-LY2459989 in greater than $99 \%$ enantiomeric purity (Fig. 4). The radiochemical purity of the product was greater than $98 \%$. The radiochemical yield was $7.4 \% \pm 3.8 \%$ at the end of synthesis (calculated from trapped ${ }^{11} \mathrm{C}$-cyanide and uncorrected for decay), with a specific activity of $22.6 \pm 0.9 \mathrm{GBq} / \mu \mathrm{mol}$ (end of synthesis, $n=16$ ). Total synthesis time was $40 \pm 5 \mathrm{~min}$. 


\section{In Vivo Evaluation in Rhesus Monkeys}

After a bolus injection of ${ }^{11} \mathrm{C}-\mathrm{LY} 2459989$ (140.6 $\pm 45.5 \mathrm{MBq}$; specific activity, $12.2 \pm 4.7 \mathrm{GBq} / \mu \mathrm{mol}$ at time of injection; injected mass, $4.8 \pm 0.7 \mu \mathrm{g}, n=12$ ) into a rhesus monkey, total activity and parent activity in the plasma exhibited a rapid rise and clearance phase and then either stabilized or decreased slowly over time (Fig. 5A). At $30 \mathrm{~min}$ after tracer injection, parent fraction was approximately $25 \%$, indicating a fairly rapid metabolism of the radioligand (Fig. 5B). The plasma-free fraction of ${ }^{11} \mathrm{C}-\mathrm{LY} 2459989$ was about $4.6 \%$, compared with less than $1 \%$ for ${ }^{11} \mathrm{C}-\mathrm{LY} 2795050$ (29).

In the rhesus monkey brain, ${ }^{11} \mathrm{C}-\mathrm{LY} 2459989$ displayed good uptake and a heterogeneous distribution pattern (Fig. 6A). The nonselective opioid antagonist naloxone at a dose of $1 \mathrm{mg} / \mathrm{kg}$ reduced ${ }^{11} \mathrm{C}$-LY2459989 uptake in all brain regions to nearly homogeneous levels (Fig. 6B), an effect similarly induced by $0.3 \mathrm{mg} / \mathrm{kg}$ of the selective KOR antagonist LY2456302 (Fig. 6C).

Time-activity curves of ${ }^{11} \mathrm{C}$-LY2459989 in selected brain regions are presented in Figure 7. Higher uptake was seen in the globus pallidus, cingulate cortex, insula, caudate, and putamen; lower in the frontal cortex and thalamus; and lowest in the cerebellum (Fig. 7A). Regional activity in the brain typically reached peak levels within 10-20 min after tracer injection, indicating fast uptake kinetics. When naloxone was given before ${ }^{11} \mathrm{C}-\mathrm{LY} 2459989$, time-

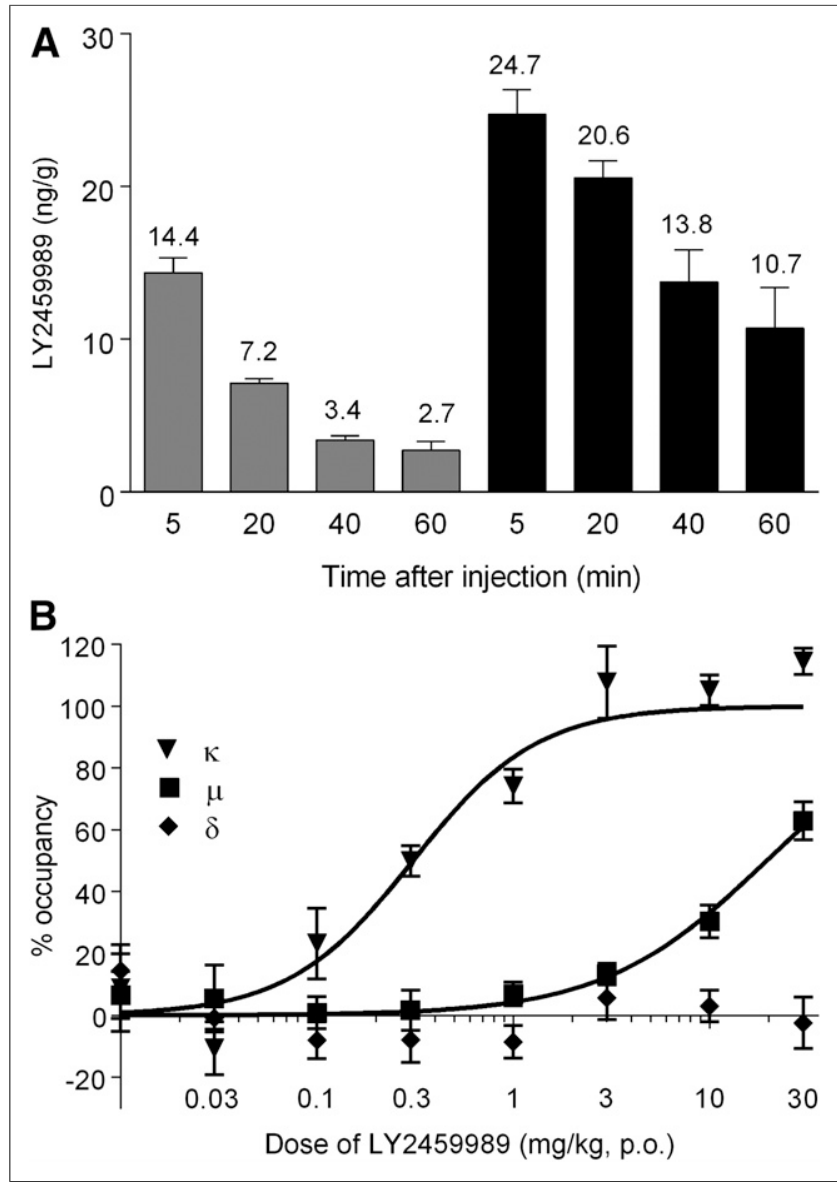

FIGURE 3. (A) Ligand concentrations ( $\mathrm{ng} / \mathrm{g}$ of brain tissue) in cerebellum (gray bar) and striatum (black bar) of Sprague-Dawley rats at 5, 20,40 , and $60 \mathrm{~min}$ ( $n=4$ rats per time point) after intravenous administration of LY2459989 (3 $\mu \mathrm{g} / \mathrm{g})$. (B) Dose-receptor occupancy relationship of LY2459989 at KOR, MOR, and DOR. p.o. = oral administration.
(S)

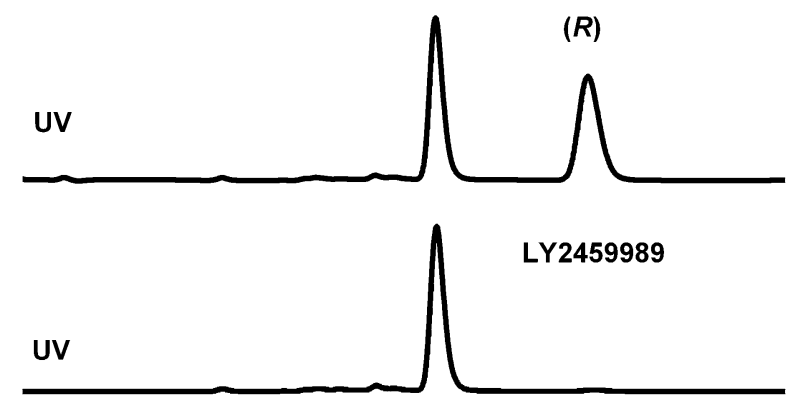

(R)-Enantiomer

UV

\section{(R) Enantiomer}
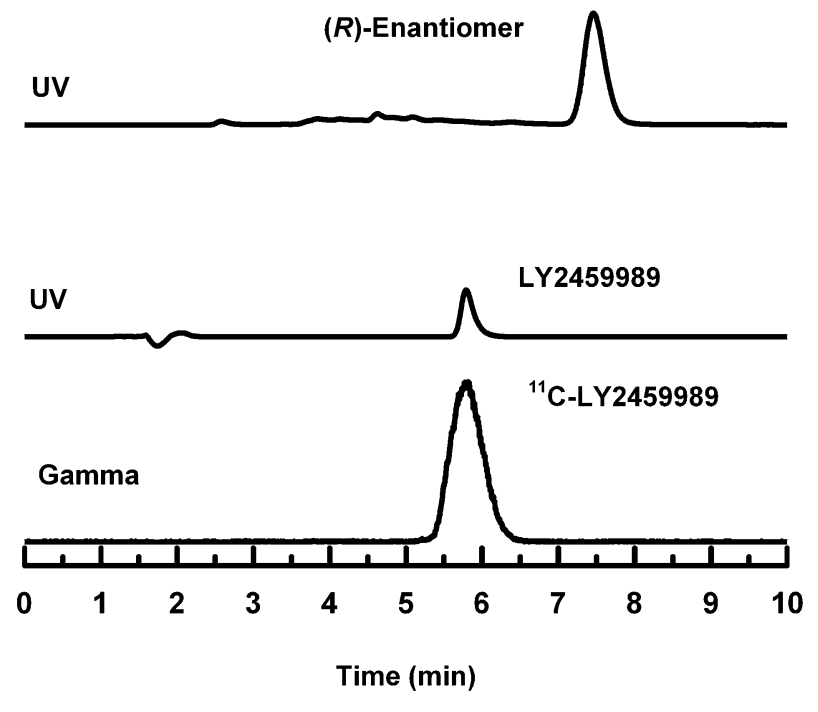

FIGURE 4. Chiral HPLC chromatograms for the racemic compound (first row), (S)-enantiomer LY2459989 (second row), (R)-enantiomer (third row), and radiolabeled compound ${ }^{11} \mathrm{C}$ - LY2459989 (last 2 rows). The (S)enantiomer eluted first at $5.4 \mathrm{~min}$, and $(R)$-enantiomer eluted later at $7.5 \mathrm{~min}$.

activity curves in higher binding regions trended down to the same level as that in the cerebellum (Fig. 7B). Furthermore, regional uptake of ${ }^{11} \mathrm{C}$-LY2459989 was also markedly reduced by pretreatment with LY2456302 (0.3 mg/kg, Fig. 7C).

Regional time-activity curves were analyzed with $1 \mathrm{~T}$ and $2 \mathrm{~T}$ compartment models (36) and the MA1 method (35) using the metabolite-corrected plasma input function. The $2 \mathrm{~T}$ model was
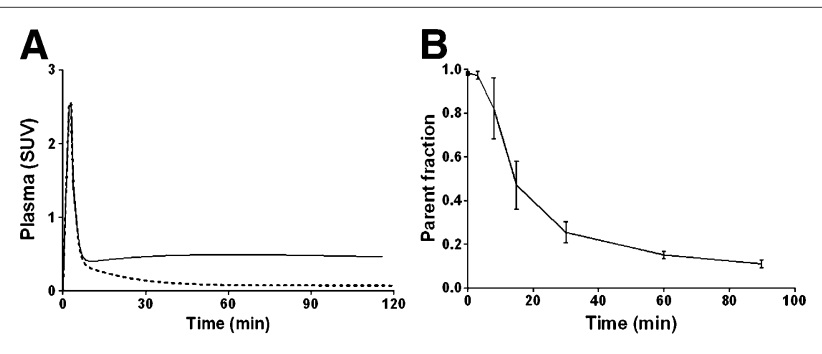

FIGURE 5. Analysis of ${ }^{11} \mathrm{C}-\mathrm{LY} 2459989$ in plasma. (A) Total radioactivity (solid line) and metabolite-corrected parent activity (dotted line) over time. (B) Time course of parent fraction from 6 baseline scans (mean \pm SD). SUV = standardized uptake value. 


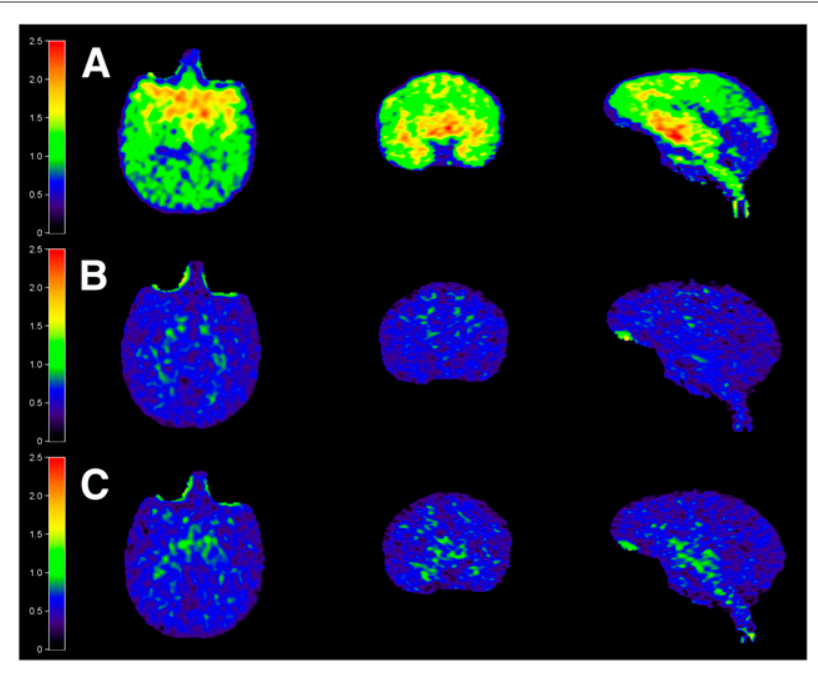

FIGURE 6. PET images of ${ }^{11} \mathrm{C}-\mathrm{LY} 2459989$ in transaxial (left), coronal (middle), and sagittal (right) views from baseline (A) and blocking scans with $1 \mathrm{mg} / \mathrm{kg}$ of naloxone (B) or $0.3 \mathrm{mg} / \mathrm{kg}$ of LY2456302 (C). Images are summed from 30 to $45 \mathrm{~min}$ after ${ }^{11} \mathrm{C}$-LY2459989 injection and presented in standardized uptake value unit.

found to provide better fits to the data than the $1 \mathrm{~T}$ model (AIC $[2 \mathrm{~T}]<\mathrm{AIC}[1 \mathrm{~T}])$. Therefore, the $2 \mathrm{~T}$ would be considered an appropriate model for analysis of the imaging data. Regional $V_{\mathrm{T}}$ values $\left(\mathrm{mL} \cdot \mathrm{cm}^{-3}\right)$ estimated by MA1 showed high correlation with $2 \mathrm{~T}$ values $\left(V_{\mathrm{T}(\mathrm{MA} 1)}=0.987 V_{\mathrm{T}(2 \mathrm{~T})}+0.027, r^{2}=0.994\right)$. Listed in Table 1 are MA1-derived $V_{\mathrm{T}}$ values. Regional values of nondisplaceable binding potential $\left(B P_{\mathrm{ND}}\right)$, as a measure of specific binding signal, were calculated using the cerebellum as the reference region (Table 2). In the baseline scans, MA1-derived $V_{\mathrm{T}}$ or $B P_{\mathrm{ND}}$ values followed the order of globus pallidus $>$ cingulate cortex $>$ insula $\sim$ caudate $\sim$ putamen $>$ frontal cortex $\sim$ temporal cortex $\sim$ thalamus $>$ cerebellum. When the monkeys were pre- treated with naloxone $(1 \mathrm{mg} / \mathrm{kg})$, LY2456302 $(0.3 \mathrm{mg} / \mathrm{kg})$, or unlabeled LY2459989 $(36 \mu \mathrm{g} / \mathrm{kg})$, the specific binding of ${ }^{11}$ C-LY2459989 was significantly blocked, as reflected by the negligible $B P_{\mathrm{ND}}$ values in most brain regions. On the basis of the occupancy plot analysis of the MA1-derived $V_{\mathrm{T}}$ values (37), 91\% \pm $2 \%$ of KOR was occupied by $1 \mathrm{mg} / \mathrm{kg}$ of naloxone in 2 monkeys. KOR occupancies of $77 \%$ and $93 \%$, respectively, were induced by 0.03 and $0.3 \mathrm{mg} / \mathrm{kg}$ of LY2456302, whereas an occupancy of $72 \% \pm$ $5 \%$ was achieved in the self-blocking experiments with $36 \mu \mathrm{g} / \mathrm{kg}$ of LY2459989 in 2 separate monkeys.

\section{DISCUSSION}

In this paper, we describe the synthesis and evaluation of ${ }^{11} \mathrm{C}$ LY2459989 as an improved antagonist radiotracer for PET imaging of KOR in rhesus monkeys. ${ }^{11} \mathrm{C}$-LY2459989 is a fluorine-containing analog of ${ }^{11} \mathrm{C}-\mathrm{LY} 2795050$, a first antagonist tracer developed at our laboratory and shown to be suitable for in vivo imaging and quantification of KOR in nonhuman primates (29). LY2459989 was synthesized in a route similar to that for LY2795050 (30). In radioligand competition assays in vitro, LY2459989 displayed high KOR binding affinity $\left(K_{\mathrm{i}}=0.18 \mathrm{nM}\right)$ and more than 43 -fold selectivity for KOR over other ORs $\left(K_{\mathrm{i}}=7.68 \mathrm{nM}\right.$ for MOR and $91.3 \mathrm{nM}$ for DOR). Compared with LY2795050 $\left(K_{\mathrm{i}}=0.72 \mathrm{nM}\right.$ for KOR), LY2459989 exhibited 4-times-higher KOR affinity and similar selectivity. Given this favorable in vitro binding profile, ex vivo evaluation was performed in rodents to assess its potential as a tracer candidate.

LY2459989 was administered intravenously to rats at a dose of 3 $\mu \mathrm{g} / \mathrm{kg}$. This dose was selected to be low enough to approximate tracer conditions while allowing the accurate measurement of tissue concentrations by LC/MS/MS analysis (32). LY2459989 was found to have excellent brain penetration, with initial uptake levels of 24.7 and 14.4 $\mathrm{ng} / \mathrm{g}$ in the striatum and cerebellum at $5 \mathrm{~min}$ after injection, which were more than 6 times higher than those of LY2795050 (4.0 and 2.0 ng/g) (29). Specific binding of LY2459989 was also higher, with striatum-to-cerebellum ratios of 4.1 and 4.0 at 40 and $60 \mathrm{~min}$ after injection, respectively, versus 2.2 and 3.3 for LY2795050 (29).

Receptor occupancies at the rat KOR, MOR, and DOR were also assessed with LC/MS/MS after oral administration of ascending doses of LY2459989 using the tripletracer method, with intravenous injection of GR103545 $(1.5 \mu \mathrm{g} / \mathrm{kg})$, naltrexone (10 $\mu \mathrm{g} / \mathrm{kg})$, and naltriben $(10 \mu \mathrm{g} / \mathrm{kg})$ as tracers for measuring binding to KOR, MOR, and DOR (32). KOR and MOR binding was reduced by LY2459989 in a dose-dependent manner. From the saturation curves, the LY2459989 $E D_{50}$ was calculated to be $0.31 \mathrm{mg} / \mathrm{kg}$ for KOR and $19.5 \mathrm{mg} / \mathrm{kg}$ for MOR, which corresponded to about 63-fold KOR/MOR selectivity in vivo, consistent with the approximate 43-times KOR/MOR selectivity measured in vitro.

The radiolabeled ligand ${ }^{11} \mathrm{C}-\mathrm{LY} 2459989$ was prepared in high radiochemical purity in a 2-step radiosynthetic pathway using ${ }^{11} \mathrm{C}-\mathrm{HCN}$ as the radiolabeling agent. The reaction conditions used in the radiosynthesis

FIGURE 7. Time-activity curves in selected brain regions from ${ }^{11} \mathrm{C}-\mathrm{LY} 2459989$ baseline scan and blocking scans after naloxone (B), $0.3 \mathrm{mg} / \mathrm{kg}$ of LY2456302 (C), or $36 \mu \mathrm{g} / \mathrm{kg}$ of LY2459989 (D). 
TABLE 1

Regional $V_{\mathrm{T}}$ Values of ${ }^{11} \mathrm{C}$-LY2459989 Under Different Conditions

\begin{tabular}{|c|c|c|c|c|c|c|c|c|c|c|}
\hline \multirow[b]{2}{*}{ Condition } & \multirow[b]{2}{*}{$\begin{array}{l}\text { Blocking drug } \\
\text { dose (mg/kg) }\end{array}$} & \multicolumn{9}{|c|}{$V_{\mathrm{T}}\left(\mathrm{mL} \cdot \mathrm{cm}^{-3}\right)$} \\
\hline & & $\begin{array}{l}\text { Globus } \\
\text { pallidus }\end{array}$ & Caudate & Putamen & $\begin{array}{l}\text { Cingulate } \\
\text { cortex }\end{array}$ & Insula & $\begin{array}{l}\text { Frontal } \\
\text { cortex }\end{array}$ & $\begin{array}{c}\text { Temporal } \\
\text { cortex }\end{array}$ & Thalamus & Cerebellum \\
\hline Baseline $(n=6)$ & - & $12.7 \pm 1.6$ & $8.2 \pm 1.4$ & $8.1 \pm 1.2$ & $9.6 \pm 2.0$ & $8.4 \pm 1.3$ & $6.4 \pm 1.0$ & $6.1 \pm 0.8$ & $6.0 \pm 0.9$ & $4.0 \pm 0.6$ \\
\hline Naloxone $(n=2)$ & 1.0 & $5.2 \pm 0.6$ & $4.9 \pm 0.6$ & $5.3 \pm 0.8$ & $4.9 \pm 1.0$ & $4.6 \pm 0.7$ & $4.4 \pm 0.8$ & $4.1 \pm 0.5$ & $4.8 \pm 0.8$ & $4.3 \pm 0.6$ \\
\hline LY2456302 $(n=1)$ & 0.03 & 5.2 & 4.4 & 4.2 & 4.9 & 4.2 & 3.7 & 3.5 & 4.3 & 3.2 \\
\hline LY2456302 $(n=1)$ & 0.3 & 4.2 & 4.2 & 4.4 & 4.2 & 3.8 & 3.7 & 3.7 & 4.2 & 3.8 \\
\hline LY2459989 $(n=2)$ & 0.036 & $6.5 \pm 2.1$ & $5.3 \pm 1.3$ & $5.0 \pm 0.8$ & $5.6 \pm 1.6$ & $5.1 \pm 1.3$ & $4.5 \pm 0.9$ & $4.3 \pm 0.6$ & $4.9 \pm 0.8$ & $3.9 \pm 0.1$ \\
\hline $\begin{array}{l}{ }^{11} \mathrm{C}-\mathrm{LY} 2795050 \\
\text { baseline }(n=4)^{\star}\end{array}$ & & $5.2 \pm 1.4$ & $3.0 \pm 1.4$ & $4.2 \pm 0.5$ & $3.7 \pm 1.4$ & $3.4 \pm 1.0$ & $3.0 \pm 1.1$ & $2.8 \pm 0.9$ & - & $2.4 \pm 0.6$ \\
\hline
\end{tabular}

*Taken from Zheng et al. (29).

Data are mean $\pm S D$, where applicable.

did not lead to any racemization of the chiral structure and thus resulted in high enantiomeric purity $(>99 \%)$ of the product.

PET imaging experiments in rhesus monkeys indicated a fairly rapid rate of metabolism for ${ }^{11} \mathrm{C}$-LY2459989, with approximately $25 \%$ of parent tracer remaining in the plasma at $30 \mathrm{~min}$ after injection. Similarly, fast uptake kinetics were detected in the monkey brain, with peak uptake times within 10-20 min after tracer administration. The distribution of ${ }^{11} \mathrm{C}-\mathrm{LY} 2459989$ was consistent with the rank order of KOR concentrations in monkey brain regions. Regional time-activity curves were amenable to kinetic analysis by the $2 \mathrm{~T}$ model and MA1 method to derive reliable estimates of binding parameters $\left(V_{\mathrm{T}}\right.$ and $\left.B P_{\mathrm{ND}}\right)$. In blocking experiments, the binding of ${ }^{11} \mathrm{C}$-LY2459989 in KOR-rich regions was significantly reduced by pretreatment of the monkeys with either the nonselective OR antagonist naloxone $(1 \mathrm{mg} / \mathrm{kg})$ or the unlabeled LY2459989 $(36 \mu \mathrm{g} / \mathrm{kg})$. In addition, pretreatment with the selective KOR antagonist LY2456302 decreased ${ }^{11} \mathrm{C}$-LY2459989 binding in a dose-dependent manner. Further, $V_{\mathrm{T}}$ remained largely unchanged in the cerebellum when various blocking drugs were administered, suggesting that, in the rhesus monkey, the cerebellum could be used as a reference region. As a measure of specific binding signals, $B P_{\mathrm{ND}}$ was calculated from MA1-derived $V_{\mathrm{T}}$ using cerebellum as the reference region. Values of $B P_{\mathrm{ND}}$ were high, and greater than 0.5 in most brain regions, and thus can be reliably measured from kinetic analysis of PET imaging data (Table 1) (39). Taken together, results from the current study demonstrated several favorable characteristics of ${ }^{11}$ C-LY2459989 as a PET imaging tracer, such as fast uptake kinetic, specific and selective binding to $\mathrm{KOR}$, and high specific binding signals in vivo.
Compared with ${ }^{11} \mathrm{C}-\mathrm{LY} 2795050$, the new PET radioligand ${ }^{11} \mathrm{C}$ LY2459989 displays higher in vitro binding affinity for KOR with similar selectivity over other ORs. In rhesus monkeys, both tracers display good brain uptake (peak standardized uptake value, $\sim 3$ ) and fast tissue kinetics, with peak uptake levels within 10-20 min after injection. Because of the higher KOR binding affinity, specific binding of ${ }^{11} \mathrm{C}-\mathrm{LY} 2459989$ is much higher, with regional $B P_{\mathrm{ND}}$ values more than twice of those for ${ }^{11} \mathrm{C}$-LY2795050 in the monkey brain (Table 2).

\section{CONCLUSION}

In this report, we demonstrate that the novel radioligand ${ }^{11} \mathrm{C}$ LY2459989 exhibits a favorable metabolic profile, brain uptake kinetics appropriate for a ${ }^{11} \mathrm{C}$ tracer, and high regional specific binding signals in rhesus monkeys. Hence, ${ }^{11}$ C-LY2459989 represents a much improved radiotracer for PET imaging and quantification of KOR in vivo.

\section{DISCLOSURE}

The costs of publication of this article were defrayed in part by the payment of page charges. Therefore, and solely to indicate this fact, this article is hereby marked "advertisement" in accordance with 18 USC section 1734 . The study was supported by a grant from the National Institute of Mental Health (R21MH092664). This publication was also made possible by CTSA grant number UL1 RR024139 from the National Center for Research Resources (NCRR) and the National Center for Advancing Translational

TABLE 2

Regional $B P_{\mathrm{ND}}$ Values of ${ }^{11} \mathrm{C}-\mathrm{LY} 2459989$ Under Different Conditions

\begin{tabular}{|c|c|c|c|c|c|c|c|c|c|}
\hline \multirow[b]{2}{*}{ Condition } & \multirow[b]{2}{*}{$\begin{array}{l}\text { Blocking drug } \\
\text { dose }(\mathrm{mg} / \mathrm{kg})\end{array}$} & \multicolumn{8}{|c|}{$B P_{\mathrm{ND}}$} \\
\hline & & $\begin{array}{l}\text { Globus } \\
\text { pallidus }\end{array}$ & Caudate & Putamen & $\begin{array}{l}\text { Cingulate } \\
\text { cortex }\end{array}$ & Insula & $\begin{array}{l}\text { Frontal } \\
\text { cortex }\end{array}$ & $\begin{array}{l}\text { Temporal } \\
\text { cortex }\end{array}$ & Thalamus \\
\hline Baseline $(n=6)$ & - & $2.18 \pm 0.23$ & $1.04 \pm 0.13$ & $1.03 \pm 0.15$ & $1.39 \pm 0.25$ & $1.08 \pm 0.09$ & $0.59 \pm 0.09$ & $0.51 \pm 0.08$ & $0.50 \pm 0.11$ \\
\hline Naloxone $(n=2)$ & 1.0 & $0.20 \pm 0.04$ & $0.13 \pm 0.02$ & $0.23 \pm 0.00$ & $0.14 \pm 0.07$ & $0.07 \pm 0.01$ & $0.02 \pm 0.03$ & $-0.03 \pm 0.02$ & $0.10 \pm 0.03$ \\
\hline LY2456302 $(n=1)$ & 0.03 & 0.64 & 0.37 & 0.32 & 0.53 & 0.31 & 0.15 & 0.09 & 0.34 \\
\hline LY2456302 $(n=1)$ & 0.3 & 0.09 & 0.10 & 0.16 & 0.11 & 0.01 & -0.02 & -0.04 & 0.12 \\
\hline LY2459989 $(n=2)$ & 0.036 & $0.67 \pm 0.22$ & $0.36 \pm 0.25$ & $0.30 \pm 0.19$ & $0.44 \pm 0.30$ & $0.31 \pm 0.23$ & $0.16 \pm 0.17$ & $0.10 \pm 0.11$ & $0.25 \pm 0.20$ \\
\hline $\begin{array}{l}{ }^{11} \mathrm{C}-\mathrm{LY} 2795050 \\
\text { baseline }(n=4)^{\star}\end{array}$ & & $0.97 \pm 0.10$ & $0.32 \pm 0.26$ & $0.66 \pm 0.25$ & $0.63 \pm 0.21$ & $0.39 \pm 0.17$ & $0.30 \pm 0.16$ & $0.15 \pm 0.12$ & - \\
\hline
\end{tabular}

*Taken from Zheng et al. (29).

Data are mean $\pm S D$, where applicable. 
Science (NCATS), components of the National Institutes of Health (NIH), and NIH roadmap for Medical Research. Its contents are solely the responsibility of the authors and do not necessarily represent the official view of NIH. No other potential conflict of interest relevant to this article was reported.

\section{ACKNOWLEDGMENT}

The authors thank the staff at the Yale PET Center for their expert technical assistance.

\section{REFERENCES}

1. Dhawan BN, Cesselin F, Raghubir R, et al. International Union of Pharmacology. XII. Classification of opioid receptors. Pharmacol Rev. 1996;48:567-592.

2. Minami M, Satoh M. Molecular biology of the opioid receptors: structures, functions and distributions. Neurosci Res. 1995;23:121-145.

3. Hiller JM, Fan LQ. Laminar distribution of the multiple opioid receptors in the human cerebral cortex. Neurochem Res. 1996;21:1333-1345.

4. Mathieu-Kia AM, Fan LQ, Kreek MJ, Simon EJ, Hiller JM. $\mu$-, $\delta$ - and $\kappa$-opioid receptor populations are differentially altered in distinct areas of postmortem brains of Alzheimer's disease patients. Brain Res. 2001;893:121-134.

5. Peckys D, Landwehrmeyer GB. Expression of mu, kappa, and delta opioid receptor messenger RNA in the human CNS: a ${ }^{33} \mathrm{P}$ in situ hybridization study. Neuroscience. 1999;88:1093-1135.

6. Simonin F, Gaveriaux-Ruff C, Befort K, et al. к-opioid receptor in humans: cDNA and genomic cloning, chromosomal assignment, functional expression, pharmacology, and expression pattern in the central nervous system. Proc Natl Acad Sci USA. 1995;92:7006-7010.

7. Ko MC, Lee H, Harrison C, et al. Studies of $\mu-, \kappa^{-}$, and $\delta$-opioid receptor density and $\mathrm{G}$ protein activation in the cortex and thalamus of monkeys. J Pharmacol Exp Ther. 2003;306:179-186.

8. Slater P, Cross AJ. Autoradiographic distribution of dynorphin1-9 binding sites in primate brain. Neuropeptides. 1986;8:71-76.

9. Tejeda HA, Shippenberg TS, Henriksen R. The dynorphin/к-opioid receptor system and its role in psychiatric disorders. Cell Mol Life Sci. 2012;69:857-896.

10. McLaughlin JP, Marton-Popovici M, Chavkin C. Kappa opioid receptor antagonism and prodynorphin gene disruption block stress-induced behavioral responses. J Neurosci. 2003;23:5674-5683.

11. Newton SS, Thome J, Wallace TL, et al. Inhibition of cAMP response elementbinding protein or dynorphin in the nucleus accumbens produces an antidepressant-like effect. J Neurosci. 2002;22:10883-10890.

12. Shirayama Y, Ishida H, Iwata M, Hazama GI, Kawahara R, Duman RS. Stress increases dynorphin immunoreactivity in limbic brain regions and dynorphin antagonism produces antidepressant-like effects. J Neurochem. 2004;90:1258-1268.

13. Carlezon WA Jr, Beguin C, DiNieri JA, et al. Depressive-like effects of the kappa-opioid receptor agonist salvinorin A on behavior and neurochemistry in rats. J Pharmacol Exp Ther. 2006;316:440-447.

14. Beardsley PM, Howard JL, Shelton KL, Carroll FI. Differential effects of the novel kappa opioid receptor antagonist, JDTic, on reinstatement of cocaineseeking induced by footshock stressors vs cocaine primes and its antidepressant-like effects in rats. Psychopharmacology (Berl). 2005;183:118-126.

15. Mague SD, Pliakas AM, Todtenkopf MS, et al. Antidepressant-like effects of kappa-opioid receptor antagonists in the forced swim test in rats. J Pharmacol Exp Ther. 2003;305:323-330.

16. Reindl JD, Rowan K, Carey AN, Peng X, Neumeyer JL, McLaughlin JP. Antidepressant-like effects of the novel kappa opioid antagonist MCL-144B in the forced-swim test. Pharmacology. 2008;81:229-235.

17. O'Malley SS, Froehlich JC. Advances in the use of naltrexone: an integration of preclinical and clinical findings. Recent Dev Alcohol. 2003;16:217-245.

18. Shippenberg TS, Zapata A, Chefer VI. Dynorphin and the pathophysiology of drug addiction. Pharmacol Ther. 2007;116:306-321.
19. Henriksen G, Willoch F. Imaging of opioid receptors in the central nervous system. Brain. 2008;131:1171-1196.

20. Dannals RF. Positron emission tomography radioligands for the opioid system. J Labelled Comp Radiopharm. 2013;56:187-195.

21. Chesis PL, Welch MJ. Synthesis and in vitro characterization of fluorinated U50488 analogs for PET studies of kappa opioid receptors. Int J Rad Appl Instrum [A]. 1990;41:267-273.

22. Noble G, Dannals RF, Ravert HT, Wilson AA, Wagner HN. Synthesis of a radiotracer for studying k-subtype opiate receptors: $N$-[ ${ }^{11} \mathrm{C}$-methyl $]-N$-(trans-2-pyrrolidinylcyclohexyl)-3,4-dichlorophenylacetamide ([$\left.\left[{ }^{11} \mathrm{C}\right]-( \pm)-\mathrm{U}-50488 \mathrm{H}\right)$. J Labelled Comp Radiopharm. 1992;31:81-89.

23. Ravert HT, Mathews WB, Musachio JL, Scheffel U, Finley P, Dannals RF. $\left[{ }^{11} \mathrm{C}\right]-$ Methyl 4-[(3,4-dichlorophenyl)acetyl]-3-[(1-pyrrolidinyl)-methyl]-1-piperazinecarboxylate ( $\left.\left[{ }^{11} \mathrm{C}\right] \mathrm{GR} 89696\right)$ : synthesis and in vivo binding to kappa opiate receptors. Nucl Med Biol. 1999;26:737-741.

24. Ravert HT, Scheffel U, Mathews WB, Musachio JL, Dannals RF. $\left[{ }^{11} \mathrm{C}\right]-$ GR89696, a potent kappa opiate receptor radioligand; in vivo binding of the $\mathrm{R}$ and S enantiomers. Nucl Med Biol. 2002;29:47-53.

25. Tomasi G, Nabulsi N, Zheng MQ, et al. Determination of in vivo $B_{\max }$ and $K_{\mathrm{d}}$ for ${ }^{11} \mathrm{C}-\mathrm{GR} 103545$, an agonist PET tracer for kappa-opioid receptors: a study in nonhuman primates. J Nucl Med. 2013;54:600-608.

26. Talbot PS, Narendran R, Butelman ER, et al. ${ }^{11} \mathrm{C}-\mathrm{GR} 103545$, a radiotracer for imaging kappa-opioid receptors in vivo with PET: synthesis and evaluation in baboons. J Nucl Med. 2005;46:484-494.

27. Schoultz BW, Hjornevik T, Willoch F, et al. Evaluation of the kappa-opioid receptor-selective tracer $\left[{ }^{11} \mathrm{C}\right] \mathrm{GR} 103545$ in awake rhesus macaques. Eur J Nucl Med Mol Imaging. 2010;37:1174-1180.

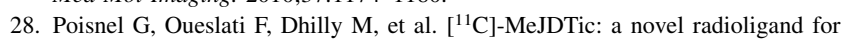
kappa-opioid receptor positron emission tomography imaging. Nucl Med Biol. 2008;35:561-569.

29. Zheng MQ, Nabulsi N, Kim SJ, et al. Synthesis and evaluation of ${ }^{11} \mathrm{C}$ LY2795050 as a kappa-opioid receptor antagonist radiotracer for PET imaging. J Nucl Med. 2013;54:455-463.

30. Mitch CH, Quimby SJ, Diaz N, et al. Discovery of aminobenzyloxyarylamides as kappa opioid receptor selective antagonists: application to preclinical development of a kappa opioid receptor antagonist receptor occupancy tracer. J Med Chem. 2011;54:8000-8012.

31. Mansour A, Fox CA, Burke S, et al. Mu, delta, and kappa opioid receptor mRNA expression in the rat CNS: an in situ hybridization study. J Comp Neurol. 1994;350:412-438.

32. Need AB, McKinzie JH, Mitch $\mathrm{CH}$, Statnick MA, Phebus LA. In vivo rat brain opioid receptor binding of LY255582 assessed with a novel method using LC/MS/MS and the administration of three tracers simultaneously. Life Sci. 2007;81:1389-1396.

33. Nabulsi N, Huang Y, Weinzimmer D, et al. High-resolution imaging of brain 5$\mathrm{HT}_{1 \mathrm{~B}}$ receptors in the rhesus monkey using $\left[{ }^{11} \mathrm{C}\right] \mathrm{P} 943$. Nucl Med Biol. 2010;37: 205-214.

34. Hilton J, Yokoi F, Dannals RF, Ravert HT, Szabo Z, Wong DF. Column-switching HPLC for the analysis of plasma in PET imaging studies. Nucl Med Biol. 2000; 27:627-630.

35. Ichise M, Toyama H, Innis RB, Carson RE. Strategies to improve neuroreceptor parameter estimation by linear regression analysis. J Cereb Blood Flow Metab. 2002;22:1271-1281.

36. Innis RB, Cunningham VJ, Delforge J, et al. Consensus nomenclature for in vivo imaging of reversibly binding radioligands. J Cereb Blood Flow Metab. 2007;27: 1533-1539.

37. Cunningham VJ, Rabiner EA, Slifstein M, Laruelle M, Gunn RN. Measuring drug occupancy in the absence of a reference region: the Lassen plot re-visited. J Cereb Blood Flow Metab. 2010;30:46-50.

38. Chernet E, Martin LJ, Li D, et al. Use of LC/MS to assess brain tracer distribution in preclinical, in vivo receptor occupancy studies: dopamine $\mathrm{D}_{2}$, serotonin 2A and NK-1 receptors as examples. Life Sci. 2005;78:340-346.

39. Laruelle M, Slifstein M, Huang Y. Relationships between radiotracer properties and image quality in molecular imaging of the brain with positron emission tomography. Mol Imaging Biol. 2003;5:363-375. 